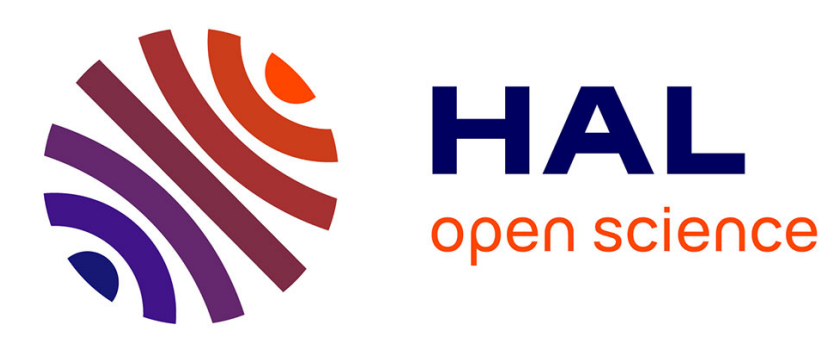

\title{
Circulation of Multiple Patterns of Unique Recombinant Forms B/CRF02_AG in France
}

\author{
M Leoz, M L Chaix, C. Delaugerre, C Rivoisy, L Meyer, C Rouzioux, F \\ Simon, J C Plantier
}

\section{- To cite this version:}

M Leoz, M L Chaix, C. Delaugerre, C Rivoisy, L Meyer, et al.. Circulation of Multiple Patterns of Unique Recombinant Forms B/CRF02_AG in France. HIV Dynamics and Evolution, 2011, Galway, Ireland. hal-02272128

HAL Id: hal-02272128

https://hal-normandie-univ.archives-ouvertes.fr/hal-02272128

Submitted on 27 Aug 2019

HAL is a multi-disciplinary open access archive for the deposit and dissemination of scientific research documents, whether they are published or not. The documents may come from teaching and research institutions in France or abroad, or from public or private research centers.
L'archive ouverte pluridisciplinaire HAL, est destinée au dépôt et à la diffusion de documents scientifiques de niveau recherche, publiés ou non, émanant des établissements d'enseignement et de recherche français ou étrangers, des laboratoires publics ou privés. 


\section{Circulation of Multiple Patterns of Unique Recombinant Forms B/CRF02_AG in France}

Precursor Signs of the Emergence of an Upcoming Circulating Recombinant Form CRF_B/02_AG?

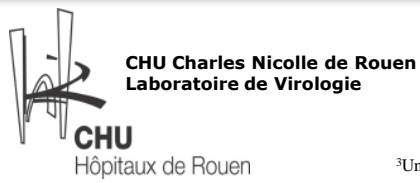

pitaux de Rouen

\section{LEOZ ${ }^{1,2}$, ML CHAIX 3 , C DELAUGERRE 4 , C RIVOISY ${ }^{3}$, L MEYER $^{5}$, C ROUZIOUX ${ }^{3}$, F SIMON $^{4}$, JC PLANTIER ${ }^{1,2}$}

'Laboratoire associé au CNR VIH, CHU Charles Nicolle, Rouen, France ; ${ }^{2}$ GRAM EA 2656, Faculté de Médecine-Pharmacie, université de Rouen, Rouen, France 'Université Paris Descartes, Faculté de Médecine, EA 3620, Paris AP-HP, Laboratoire de Virologie, CHU Necker-Enfants malades, Paris, France ${ }^{4}$ Laboratoire de Virologie, CHU Saint Louis, Paris, France

${ }^{5}$ INSERM U1018, Université Paris Sud, Faculté de Médecine Paris Sud, AP-HP, Le Kremlin Bicêtre, France

AIDS 2011, in press
Faculté de Médecine-Pharmacie Université de Rouen

\section{BACKGROUND}

HIV-1 group $M$ is characterised by substantial genetic diversity, and includes nine subtypes, more than $45 \mathrm{CRFs}$, and numerous Unique Recombinant Forms (URFs).

In France, the epidemic is characterised by :

-predominance of subtype B strains,

- increasing prevalence of non-B subtypes (fig.1), CRF02_AG being the most prevalent,

- increasing at-risk behaviour in the MSM population.

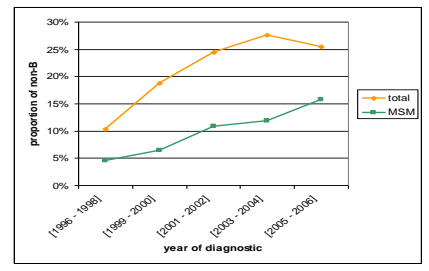

Fig.1: evolution of the proportion of non-B strains among primo-infections in France (adapted from Chaix et al, 2009)
The high prevalence and co-circulation of B and CRF02_AG strains in this population raise the possibility that recombinant forms might emerge and spread.

\section{METHODS}

Screening for subtyping discordances in different regions of the genome

Near full length sequencing and pattern characterization

Searching for parental strains or minor recombinants using Single Genome Analysis

Analysis of the phylogenetic relationships between the $\mathrm{B} / \mathrm{CRF02}$ recombinants

\section{RESULTS}

Seven samples were selected from seven patients, of whom five are MSM (tab.1)

\begin{tabular}{|c|c|c|c|c|c|c|c|c|c|c|c|}
\hline patient & sex & $\begin{array}{c}\begin{array}{c}\text { age } \\
\text { (years) }\end{array} \\
\end{array}$ & origin & risk group & $\begin{array}{c}\text { year of diagnosis of } \\
\text { HIV infection } \\
\end{array}$ & year of sampling & therapeutic status & $\begin{array}{c}\mathrm{CD4} \\
\text { (cells/mm3) }\end{array}$ & $\begin{array}{c}\text { RNA viral } \\
\text { load Log } \\
\text { copies } / \mathrm{mL} \\
\end{array}$ & $\begin{array}{l}U_{\text {URF }}^{b} \text { and } \\
\text { size (bp) }\end{array}$ & $\begin{array}{l}\text { nb of SGA } \\
\text { sequences }\end{array}$ \\
\hline P1 & M & 67 & $\begin{array}{c}\text { France } \\
\text { (caucasian) } \\
\text { France }\end{array}$ & homosexual & 2008 & 2008 & naive & 490 & 5.8 & URF1 : 8659 & 8 \\
\hline P2 & $\mathrm{F}$ & 46 & $\begin{array}{l}\text { (caucase } \\
\text { France }\end{array}$ & IDU & 2004 & 2009 & naive & 504 & 3.7 & URF2: 8891 & 11 \\
\hline P3 & M & 38 & (caucasian) & homosexual & 2006 & 2009 & treated & 549 & 5 & URF3 : 8295 & 8 \\
\hline P4 & M & $\AA^{a}$ & $\begin{array}{c}\stackrel{a}{a}^{2} \\
\text { France }\end{array}$ & $\AA^{\mathrm{a}}$ & 2002 & 2002 & $\mathrm{a}^{\mathrm{a}}$ & $a^{a}$ & 5.1 & URF4 : 8424 & 10 \\
\hline P5 & M & 25 & $\begin{array}{c}\text { (caucasian) } \\
\text { France }\end{array}$ & homosexual & 2010 & 2010 & naive & 159 & 5.1 & URF5 : 8396 & 10 \\
\hline P6 & M & 39 & $\begin{array}{c}\text { (caucasian) } \\
\text { France }\end{array}$ & homosexual & 2006 & 2006 & naive & 391 & 5.2 & URF6 : 9608 & NA \\
\hline P7 & M & 32 & (caucasian) & homosexual & 2006 & 2006 & naive & 397 & 6.2 & URF7 : 9158 & NA \\
\hline
\end{tabular}

:URF identified in the patient

NA: not applicable

Tab.1: Characteristics of the seven patients from whom the samples were selected, and of the corresponding URFs characterized a)

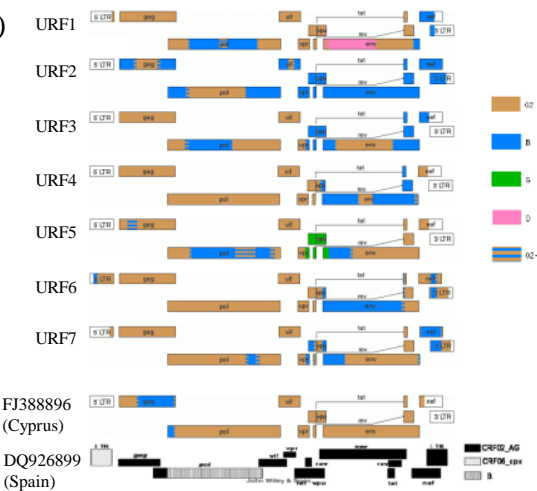

b)

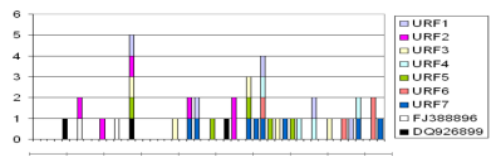

Two of the seven new URFs involve a 3rd subtype (fig. 2.a).

The seven recombination patterns are distinct from each other (fig. 2.a), and from the only two previously described B/CRF02 URFs from Cyprus (Kousiappa et al., 2009) and Spain (Holguin et al., 2008).

The breakpoints are distributed all along the genome (fig. 2.b) with hotspots in $p o l$ at the protease-to-Reverse Transcriptase border, and in $v p u$ where the overlapping start of $e n v$ is located.

Fig.2: Recombination patterns of the 7 new URFs and the 2 previously described (a) and breakpoints distribution along the genome (b)

There was no evidence of parental or minor recombinant strains circulation, although polymorphism was observed for all the strains tested (fig. 3).

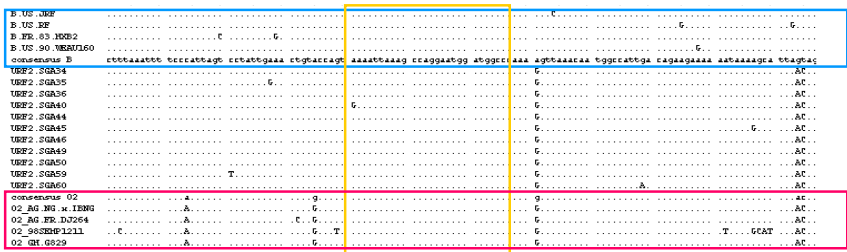

Fig.3: Example of SGA results for URF2. The 11 sequences obtained are aligned with a set of subtype B (blue box) and CRFO2 (red box) reference sequences to determine their recombination patterns; the yellow box indicates the region were recombination occured for these SGA sequences.

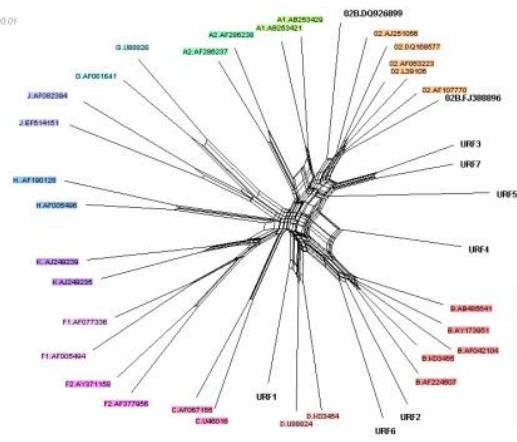

In the env gp120 region, URF3 and URF7 appeared to be linked despite their different recombination patterns.

No link was observed between any URF in the $p o l$ pr-RT region (not shown)

Fig.4: Phylogenetic network representing the relationships between the env gp120 sequences of the 9 URFs and a set of reference sequences.

\section{CONCLUSIONS}

The complexity of the molecular epidemiology is growing in France due to the raise of non-B strains prevalence and to subsequent recombinations The predominant forms, subtype B and CRF02, are co-circulating in the MSM population and frequent co-infections led to local emergence of several URFs, one of those (URF7) being linked with a cluster of CRF02_AG sequences identified in the MSM population of Paris

The absence of parental strains suggests direct transmission of these strains, indicating that they could spread in particular within this population A surveillance is needed to determine if this dynamic could lead to the genesis of a new CRF_B/CRF02_AG in France 